This is a self-archived version of an original article. This version may differ from the original in pagination and typographic details.

Author(s): Reus, Tim

Title: An Icy Force Both Foul and Fair : The Theme of Love Versus Fear in the Dutch Bubbed Version of Disney's Frozen

Year: 2020

Version: Accepted version (Final draft)

Copyright: (c) Akademiai Kiado, 2020

Rights: In Copyright

Rights url: http://rightsstatements.org/page/InC/1.0/?language=en

Please cite the original version:

Reus, T. (2020). An Icy Force Both Foul and Fair : The Theme of Love Versus Fear in the Dutch Bubbed Version of Disney's Frozen. Across Languages and Cultures, 21(1), 89-106.

https://doi.org/10.1556/084.2020.00005 


\section{An icy force both foul and fair: The theme of love versus fear in the Dutch dubbed version of Disney's Frozen}

Keywords: Dubbing, Dutch, Frozen, song translation, triangle of aspects

This study compares the songs from the original, English-language version of the 2013 Disney film Frozen to those of the Dutch dubbed version, investigating how the thematic representation of love and fear differ between these versions. To support this inherently qualitative analysis, this study employs the triangle of aspects, an analytical model that identifies certain aspects and variables central to animated musical film dubbing, allowing a quantification of differences between dubbed versions. It is found that the dubbed songs differ most strongly from the original songs in the verbal code, which covers issues such as semantic sense and register, and least in the musical code, which concerns matters of rhyme scheme, rhythm, and singability. The effects of the changes are a slight backgrounding of the theme of love versus fear: whereas the source version presents and explores a clear dichotomy between love and fear, the dubbed version concentrates more on love as the ultimate goal of life, eliminating much of the importance of fear. These results show that quantitative data can be useful in qualitative analyses, presenting an important step in the development of the field of animated musical film dubbing within translation studies. 


\section{INTRODUCTION}

Although audiovisual translation is currently a popular field among translation scholars (e.g. Pérez-González 2014; Low 2017), a genre that has seen some academic attention only in the past half a decade (as attested to by scholars including Di Giovanni 2008, Stopar 2016, and Martín-Castaño 2017) is the dubbing of musical film, and especially - even despite its significant importance in many societies today — animated musical film. The 2013 Disney film Frozen was one of the most successful films of all time around the globe (Konnikova 2014), its characters - particularly the princess sisters Elsa and Anna — and its themes - including loneliness, friendship, and the main overarching theme of love versus fear - resonating with many (Giese 2017). The Netherlands, where the dubbed version was released a mere month after the original version's release in New York (Del Vecho 2013), is one of the many countries in which the film was well-received (e.g. Wensink 2014). This study aims to explore the genre of animated musical film dubbing and evoke more academic interest in the field by conducting a case study of the songs of Frozen. The aim is to investigate how the theme of love versus fear differs between the original (or source) version and the Dutch-language dubbed version released in the Netherlands (the target version).

Since the field of animated musical film dubbing is relatively new within translation studies, this study also incorporates research into song translation and dubbing, as well as work on musicology, film studies, and literature studies, to develop an analytical model of animated musical films. This model, the triangle of aspects (Reus 2017), allows researchers to generate a comprehensive data set of differences between two versions of an animated musical film song on the basis of ten aspects. It offers useful tools for researchers of audiovisual translation, song and film translation, and musical translation, as well as dubbing history and the study of international export of Disney films. The triangle of aspects, and its use in a thematic analysis of an animated musical film, is described in more detail in section 2. That section also introduces Frozen and the theme of love versus fear in more detail. Section 3 briefly describes the results of the triangle of aspects analysis. 
Sections 4 to 6 discuss the role of love and fear in the target songs and compare it to the source version in order to uncover to what extent and in what form the theme of love versus fear is different in the target version from the source version. Section 7 draws conclusions and gives recommendations for further research.

\section{MATERIAL AND METHOD}

The triangle of aspects, an analytical model first introduced in Reus (2017), provides a quantitative basis for the investigation of the theme of love versus fear in the source and target versions of the songs from Frozen. According to this model, an animated musical film comprises three codes, or sides - the musical, the visual, and the verbal — that need to be negotiated in the dubbing process: see figure 1. The triangle of aspects consists of ten aspects that together support a thorough qualitative analysis of theme with clear, close description and measurable data. Analyses employing the triangle of aspects use the song line or the syllable as their unit of analysis, depending on the aspect, and either assign a certain value to both language versions of that line or syllable, or directly compare the source and target versions, thus assigning a value only to the target version. In this sense, the model functions as a set of guidelines or tools that facilitate research into dubbed songs from animated musical films. The primary purpose of the triangle of aspects analysis in this study is to discover which aspects and songs or passages in the target version differ most from the source version. The results of this analysis are then used to discuss how the theme of love versus fear differs in the target version from the source version. 


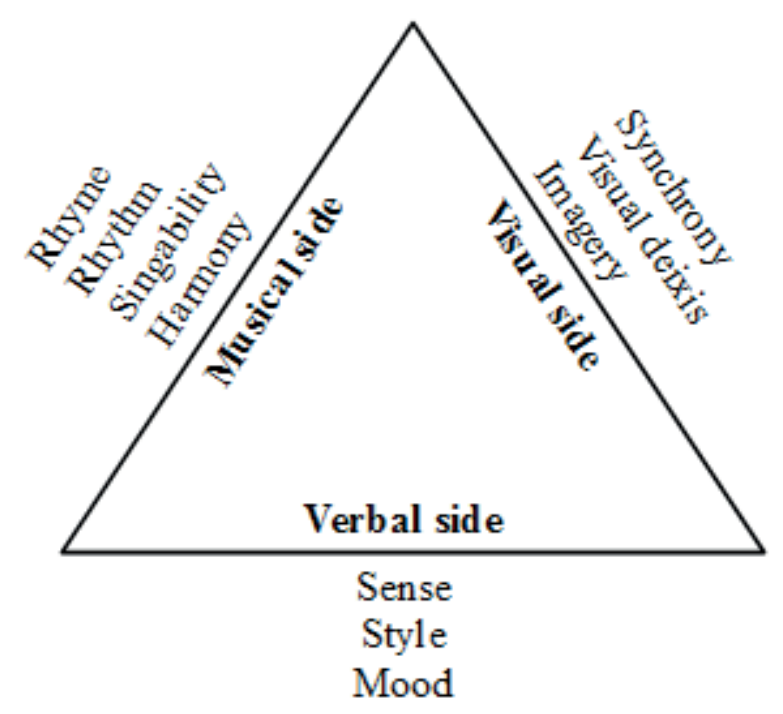

Figure 1: The triangle of aspects

The triangle of aspects' musical side consists of the four aspects of rhyme, rhythm, singability, and harmony. These are the four elements of music that constitute important constraints for song dubbing. For the aspect of rhyme, the researcher compares the rhyme schemes and number and prominence of repetitions in the source and target versions; rhythm describes the number of syllables and stress pattern per line; and singability defines how easy it is to sing the lines, using a system of categorising vowels and consonants based on Low (2005) and Franzon (2008). According to this system, open vowels are easier to sing than closed vowels, and voiceless or plosive consonants are more difficult to sing than voiced or sonorant consonants. The higher the singability, the more comfortable and confident a song sounds and the more intelligible it is. The fourth aspect, harmony, concerns the meaning of the music itself, as conveyed by its key, time signature, tempo, melody, chord structure, and orchestration (Tråvén 2005, Clendinning \& Marvin 2010). This musical meaning is compared to the meaning of the lines to describe whether the music illustrates, amplifies, or provides disjuncture to the lyrics (Kaindl 2005).

The visual side comprises the three aspects of synchrony, visual deixis, and imagery. Synchrony describes the singers' mouth movements and compares them to the syllables 
sung in the target version to find minor and major differences. Minor differences are vowels or consonants that differ one or two steps from the mouth movements seen on screen (as analysed using the IPA vowel and consonant diagrams), and major differences differ more than two steps. For this purpose, lines sung during close-ups of the singer's mouth are deemed more significant than non-close-up lines (Chaume 2012). Visual deixis concerns instances where the lyrics directly reference something seen on screen, such as characters pointing at things or an explicit description of an object (Chaume 1997, Levinson 2004). Imagery analyses the implicit meaning of the visual code, as shaped through lighting, colour, mise-en-scène, and montage (Arnheim 1974), and that meaning is compared to the lyrics to establish an illustrative, amplifying or disjunctive relationship (Kaindl 2005).

The verbal side of the triangle comprises the aspects of sense, style, and mood. Sense compares the semantic meaning of the lyrics between the source and target versions and indicates minor and major differences per line. Minor differences include partial alterations and added or removed connotations; major differences are lines with a completely different meaning (Low 2017). Style analyses the register and naturalness of the language per singer, and compares the findings between the two versions. A loose system of simple, average, and complex grammatical structures and vocabulary per song line supports this stylistic analysis (Leech \& Short 2007), but style ultimately relies on a more qualitative interpretation of the language used. Mood concerns the narrative context of the song, including the story, themes and metaphors, symbolism, and character development, and analyses the position of the song in this context (e.g. Labov \& Waletzky 1967). It is important to realise that although the verbal code is changed in the dubbing process, the verbal side of the triangle does not, necessarily. Words change, but not necessarily the meaning, style, or narrative of the song. Together, these ten aspects allow for a comprehensive understanding of the songs and the development of the themes in the target version.

This study concentrates on Frozen (Del Vecho 2013) as a representative of the 
contemporary animated musical film genre: produced by Disney, the largest producer of animated musical films (Malach 2014), it is a film in which the songs constitute an essential part of the narrative. The Netherlands saw Frozen's dubbed release on 11 December 2013 (Wensink 2014). Whereas the film itself was among the highest grossing films (Konnikova 2014), the soundtrack album was the most sold music album of 2014 (Wensink 2014) and the songs are indeed quite central to the film's success (Konnikova 2014), offering convincing character development as well as detailed thematic commentary (Beaudry 2015; Yee 2014). This study concentrates on the nine songs with English-language lyrics in the source version, which were dubbed in Dutch for the target version released in the Netherlands: 'Frozen heart', 'Do you want to build a snowman', 'For the first time in forever', 'Love is an open door', 'Let it go', 'Reindeer(s) are better than people', 'In summer', 'For the first time in forever (reprise)', and 'Fixer upper'. These songs together comprise 395 lines and around 23 minutes of audiovisual material when played back to back (Del Vecho 2013).

Based strongly in modern stage musical traditions (Beaudry 2015), the music of the film helps develop the story of two princess sisters - one cursed with magical powers she is unable to control and one isolated for most of her childhood without knowing why — that seems to resonate with many. One reason for this, suggests Yee (2014), is the film's themes. One of the primary themes is the opposition of love versus fear: love as represented by warmth, fire, passion, and togetherness; and fear as represented by coldness, ice, rationality, and isolation (Bauer \& Steiner 2015). Anna embodies the emotion of love, as well as everything it entails, her red hair and freckles representing warmth and fire and her impulsiveness and unbridled optimism displaying her passion. Throughout the film her primary goal is to connect with Elsa, first by coaxing her out of her room during their isolation in the palace and later by chasing her to the top of a mountain. Elsa, on the other hand, represents fear: she has ice powers, is cautious and fearful, and tries to isolate herself in order to protect others. Although halfway through the film it appears that Elsa has found peace and happiness in isolation, the film concludes with Elsa accepting and reciprocating Anna's love, an act that allows her to finally control her powers. But the dichotomy of love 
versus fear is not limited to the two main characters: the deceitful antagonist Hans is isolated because his parents neglected him; Anna's tentative love interest Kristoff because he was kidnapped by trolls; and the animated snowman Olaf simply because he has not seen anyone else in his short life. Kristoff and Olaf find love (and thus, redemption) by the film's conclusion, while Hans, failing to find love, faces retribution for his crimes (Yee 2014).

The theme of love versus fear can be found in all nine songs. 'Frozen heart' introduces ice as an important metaphor and highlights the importance of breaking and shaping the ice, or one's fear, rather than letting it control you. 'Do you want to build a snowman' introduces Elsa and Anna in their roles of emotional opposites: Elsa locks herself away while Anna tries to connect with her. The song, assuming the viewpoint of Anna, also introduces the ideas that love is good and fear is bad. 'For the first time in forever' narrates the story's main stimulus (i.e. Elsa's coronation) and further develops the sisters as thematic opposites. 'Love is an open door' shows Anna bonding with the first man she sees, revealing her yearning for love, but also — since that man is later revealed to be the antagonist complicating the dichotomy of love and fear by hinting at the foolishness that carelessness and passion can lead to.

'Let it go' is a thematic contrast to the previous song, highlighting Elsa's need for isolation and the freedom she experiences in her isolation, further indicating that matters are not as simple as love is good and fear is bad. In 'Reindeer(s) are better than people' and 'In summer', the story takes a break and the characters of Kristoff and Olaf, respectively, are introduced: Kristoff is bitter and dislikes society as a result of his isolation and, it could be argued, displays a fear of society similar to Elsa's; Olaf is optimistic, joyful and naive, like Anna, chasing a dream that seems impossible to achieve and longing for love. 'For the first time in forever (reprise)' is a confrontation between Elsa and Anna, during which they attempt to solve their differences but fail to understand each other's viewpoints. This song represents a climax for the theme of love versus fear, pitting the concepts against each other quite directly. 'Fixer upper', finally, is an ode to love, and describes quite explicitly how 
we need love to drive out fear. In these songs, then, as in the film as a whole, love and fear play major roles that are relevant for translation evaluations and are vulnerable to translation decisions. See table 1, below, for a summary of this expression of the theme.

\section{RESULTS}

The full data set for this study can be publicly accessed from Kielipankki (2019), the language bank of Finland. This data set comprises scans of the analysis sheets and tables offering a numerical summary of the findings. In addition, a more comprehensive discussion of the results is available in Reus (2018). This section highlights some of the most relevant results for the thematic analysis of love versus fear, describing the differences between the source and target versions of the songs - as well as, briefly, the effects of those differences on the theme of love versus fear - on the musical, visual, and verbal sides of the triangle. ${ }^{1}$ Table 1 summarises the theme of love versus fear, and the aspects that include the main differences between the source and target versions, in each song.

Table 1: The theme of love versus fear, and the main differences, per song

\begin{tabular}{|c|c|c|}
\hline Song & Relation to love and fear & Main differences in the TT \\
\hline 'Frozen heart' & Introduction of the theme & Synchrony, visual deixis, sense \\
\hline $\begin{array}{l}\text { 'Do you want to build } \\
\text { a snowman' }\end{array}$ & Introduction of Anna and love & Rhythm, synchrony \\
\hline $\begin{array}{l}\text { 'For the first time in } \\
\text { forever' }\end{array}$ & $\begin{array}{l}\text { Introduction of Elsa and fear, } \\
\text { juxtaposition of love and fear }\end{array}$ & Singability, synchrony, style \\
\hline 'Love is an open door' & Complication of love & Rhyme, rhythm, singability \\
\hline 'Let it go' & Complication of fear & Synchrony, sense, mood \\
\hline $\begin{array}{l}\text { 'Reindeer(s) are better } \\
\text { than people' }\end{array}$ & Expansion of fear & Rhyme, style \\
\hline 'In summer' & Expansion of love & Imagery \\
\hline
\end{tabular}

${ }^{1}$ All back-translations of song lyrics in the following sections are mine. 


\begin{tabular}{lll}
\hline $\begin{array}{l}\text { 'For the first time in } \\
\text { forever (reprise)' }\end{array}$ & Confrontation of love and fear & Singability, style \\
\hline 'Fixer upper' & Victory of love over fear & Singability, visual deixis \\
\hline
\end{tabular}

Of the three sides of the triangle, the musical is the most similar between the source and target versions. The target songs have slightly more different rhymes than the source songs, which means that the individual rhymes are repeated less often. The only exception to this is 'Frozen heart', which has fewer different rhymes in the target version. Rhythmically, the target version is even more similar to the source version. Most songs have seen the addition of some marked stress patterns, which are especially numerous in 'Do you want to build a snowman' ( 7 instances) and 'Love is an open door' (6 instances). For example, the first line of 'Do you want to build a snowman' is translated as 'Zullen wij een sneeuwpop maken' ('Shall we make a snowman'): this translation stresses 'wij' ('we') in favour of the most syntactically important (and naturally most strongly stressed) part of the question, 'sneeuwpop' ('snowman'), thus deviating from an unmarked stress pattern. Most songs also include at least a few lines with added or removed syllables in the target version, but these syllables were added and removed exclusively in unstressed and melodically unimportant areas.

Singability is the musical aspect that is most different in the target version from the source version, fulfilling a noticeably reduced thematic role. In 'For the first time in forever' and its reprise, for example, the source-language Elsa uses mostly close vowels while Anna uses mostly open vowels, highlighting the opposition between the characters: in the target version, this difference in singability is eliminated and the characters sing roughly equal numbers of open and close vowels. (This distinction in singability between Elsa and Anna is only present in these two songs, not in the rest of the film, so it can be argued that this was not intentionally done, but in these two songs, at least, the distinction is quite noticeable.) Concerning the relation between the lyrics and the implicit meaning of the music, the target version generally focuses more on illustration in favour of expanding, or amplifying, the meaning of the lyrics through their interaction with the music, the only 
exceptions being 'Let it go' and 'Reindeer(s) are better than people'. Apart from this slight tendency towards illustration, however, there are few significant harmonic differences between both versions.

On the visual side, and in general, the aspect of synchrony harbours the most differences of any single aspect. Especially 'Frozen heart' displays many differences, having only two prominent syllables with no difference as opposed to 12 with a minor difference and 9 with a major difference, while songs such as 'Do you want to build a snowman' and 'Let it go' also have a large degree of synchronic disagreement in the target version. Most instances of visual deixis, or direct references in the lyrics to something seen on screen, have been retained in the target version, the one notable exception again being 'Frozen heart'. The songs in which visual deixis is retained most significantly are 'For the first time in forever' and its reprise, both duets of Elsa and Anna. Imagery, or the relation between the lyrics and the implied or connotative meaning of the visual code, is very similar between both versions: in some songs in the target version the imagery is made to illustrate the lyrics more than in the source version, while in other songs it is made to amplify the lyrics more, but the differences are minor. 'In summer' is an interesting song in that the disjuncture between the bright, colourful imagery and the dramatic irony of the lyrics is weakened in the target version, which makes the irony of Olaf the snowman not knowing that snow melts in summer less sharp.

The verbal side is arguably most different in the target version. Concerning the aspect of sense, roughly half of the lines in the target version have an altered meaning or altered connotations. 'Frozen heart' is the song most semantically different in the target version, while 'Do you want to build a snowman', in which 20 of the 32 lines are unaltered, might be the most similar. 'Love is an open door' and 'Let it go' both have a considerable number of lines with major changes, which might be related to the amount of (thematic) information packed in relatively short lines. Stylistically, too, the target version shows consistent differences from the source version. In general, the target version comprises more unnatural-sounding phrases and archaisms, which replace the sometimes lyrical 
language and modern-day colloquialisms of the source version. In addition, characters' linguistic idiosyncrasies are reduced in the target version, removing the grammatical error in the titular lines of 'Reindeer(s) are better than people' and the stylistic differences in language use between Elsa and Anna in 'For the first time in forever' and its reprise. The exception to the trend of increased formality is 'Fixer upper', where some archaisms have been removed in the target version. Lastly, the mood, or the way the lyrics express the narrative context, character development, themes and motifs, is fairly similar in both versions. The target version removes some direct references to themes and symbols, but generally compensates for those losses in other lines. This strategy of compensation, however, may alter the interpretation of symbols: the target version line 32 of 'Let it go' ('I'm one with the wind and sky' in the source version) is 'Voorbij is de storm in mij' ('The storm in me is over'), and while this line should sound empowering for Elsa, this interpretation becomes problematic if the storm is to still represent her liberation. In this sense, most songs' mood has been altered, but also compensated for.

\section{LOVE IN THE TARGET VERSION}

Anna can be seen as a symbol of love throughout the film. This is especially the case in 'Do you want to build a snowman' and 'Love is an open door', where she displays the desire to establish intimate connections with people - with Elsa, representing familial ties, in the former, and Hans, representing romantic love, in the latter. 'Do you want to build a snowman' represents not only Anna's love, but also her longing for love and her confusion towards Elsa's choice for isolation. It intersperses moments of clarity (such as the titular lines 2, 10-11, 14, and 32, where the snowman represents the connection between her and Elsa) with moments of great uncertainty (such as lines 4-5, 'I never see you anymore / Come out the door', sung over a minor chord progression and with lower singability as well as a visually darker colour palette). The target version maintains the semantic distinction between certainty and uncertainty in the aspect of sense, but weakens it by levelling singability (i.e. the singability for lines expressing certainty and for those expressing uncertainty is roughly equal in the target version). A great example of this is line 10 , 'Do 
you want to build a snowman', which is translated as 'Kom, dan maken we een sneeuwpop' ('Come on, let's build a snowman'). The two melodically stressed syllables, 'snow' and 'man', have a high singability in the source version (/o:/ and /æ:/ are quite open vowels), whereas the target version has / I $\mathrm{u} /$ and / $/$ /, closer and shorter vowels, and ends in a voiceless plosive consonant. Reduced repetition and the considerable degree of synchronic differences (see the above line 10 for an example of synchronic differences, too) reinforce the perception of Anna's insecurities. While the source version maintains a fairly sharp distinction between lines expressing love and lines expressing longing or confusion, the target version levels that distinction and instead introduces more uncertainty into the song as a whole. As a result, the target version has no lines that express Anna's intention to love as strongly as the source version, weakening her resolve as well as the introduction of the theme of love in the film.

'Love is an open door' symbolises not only (romantic) love, but also Anna's social ineptitude, which is used to express the notion that love cannot be forced. Anna's longing for affection causes her to rush into a relationship, but - as becomes apparent over the course of the song - Anna and Hans do not actually know each other (with lines such as 19, sung by Hans, and 20, the response by Anna: 'We finish each others / Sandwiches'). The translation of lines 19-20, 'We geven elkaar een / Hapje taart' ('We give each other a / Piece of cake'), is a good example of how this narrowing down of the theme of love has been effected: the target version focuses purely on the explicit love presented in the song - Anna finally finding the love she had been looking for all her life - and ignores the implicit foreshadowing of Hans eventually betraying Anna. This focus of the target text on love more than on Hans's eventual betrayal can also be observed in the song's singability (which is considerably higher, thus more comfortable, clear and unobstructed, in the target version) and imagery, but is countered to a certain extent by the greatly reduced repetition between Anna's and Hans's lines and the introduction of unnatural stress in the target version. Overall, however, there are more aspects that support an uncomplicated expression of love (i.e. singability, imagery, and sense) than aspects that support the incongruity between Hans and Anna (i.e. rhyme and rhythm) in the target version. 


\section{FEAR IN THE TARGET VERSION}

Fear is a prominent theme of 'Let it go', sung by Elsa, as well as 'Reindeer(s) are better than people', sung by Kristoff. 'Let it go' represents a significant shift in Elsa's character from fearful and oppressed (by society as well as herself) to liberated and in control of her powers. The storm, as a symbol of her ice powers, initially represent fear, but later liberation and confidence, and the cold and distance she once feared are now symbols of positive isolation. When Elsa sings her childhood mantra (which previously fostered the fear within her), 'Don't let them in / Don't let them see' and 'Conceal, don't feel / Don't let them know' (lines 8-9 and 12-13, respectively), the music is upbeat and major, and the screen is lit up by magic and curly shapes: she is no longer afraid. The target version does not use her childhood mantra for these lines, instead opting for a more literal translation and thereby severing the relation between Elsa's current state of mind and her childhood. In addition, the metaphor of the storm has become confused in the target version, representing, as in the source version, both her ice powers and her fears, but not transforming into liberation over the course of the song. Musically, the target version is quite close to the source version, but visually it includes quite numerous synchronic differences, making Elsa appear more confused. A striking example of this is line 15, 'Let it go, let it go', translated as 'Laat het los, laat het gaan' ('Let it go, let it go'). The first instance of the phrase is quite similar, synchronically, but the second (possibly motivated by the higher singability of ' $g a a n$ ', /xa:n/) results in a significant difference between the the shape of Elsa's mouth and the shape a mouth normally makes when producing this sound. In addition, some important instances of visual deixis are removed, especially towards the end, where the source version portrays Elsa as having conquered her childhood fears convincingly. A great example is line 38, 'My power flurries through the air into the ground', translated as 'Mijn kracht neemt toe en schept een zuilenrij van steen' ('My power increases and creates a colonnade of stone'). While singing this line, Elsa is creating the foundation of a castle, not a colonnade, of ice, not of stone, which makes her sound detached or confused. In the target version, Elsa's development is in general less 
convincing and pronounced, and the 'fears that once controlled [her]' (line 25) are still quite tangible by the end.

In the sense of finding happiness in isolation (as well as in the sense of later being reintroduced to society by Anna), Kristoff is similar to Elsa. As a child he was kidnapped by trolls, who raised him as an ice miner, and the first time the audience sees him interact with humans he is gruff, hostile, and unable to acquire what he wants. In 'Reindeer(s) are better than people', taking place right after this incident, Kristoff bemoans human society in a way that highlights his happiness with being alone. Even though it is not overt, the song displays Kristoff's fear of society in lines such as 3-5, 'Yeah people will beat you / And curse you and cheat you / Every one of them is bad'. Interestingly, the sections in which Kristoff sings about humans have a significantly lower singability than the sections where he sings about reindeer or himself, but they contain significantly more repetition. The target version lines 3-5, 'Ja mensen bedriegen / Ze vechten en liegen / Ze zijn stuk voor stuk slecht' ('Yeah people cheat / They fight and lie / Every one of them is bad'), are less personal than the source version, omitting the pronouns referring to Kristoff, but otherwise convey a similar sense of dissatisfaction with society. However, the target version includes no difference in rhyme or singability between the different subjects addressed, thus incorporating Kristoff's fear of society more effortlessly into his love of reindeer. This strategy, like the strategy used in 'Let it go', complicates a clear dichotomy between fear and love and foreshadows Elsa's and Kristoff's reintegration and eventual suggested happiness in society.

\section{LOVE VERSUS FEAR}

The central development of love and fear in the film, however, is the opposition between them, which can also be interpreted as the juxtaposition of Anna and Elsa. This opposition is the focus of two songs: 'For the first time in forever' and its reprise. Both are duets of Elsa, representing fear, caution, and isolation; and Anna, representing love, passion, and bonding. In the first song, Anna describes the way the palace opens up in preparation for 
Elsa's coronation, and displays great joy and excitement at the prospect of meeting new people. Elsa, on the other hand, sits quietly in her room and repeats her childhood mantra ('Don't let them in / Don't let them see', lines 37-38). Musically, Anna's verses employ a predominantly major chord structure while Elsa's employ a relative minor chord structure and more subdued orchestration; visually, Elsa's verses are darker and include less movement than Anna's. The difference in the sisters' approaches to dealing with the situation is significant, but there are also similarities. Singability is again used as a distinguishing factor between the fears of Elsa and the love and excitement of Anna, while rhyme and repetition show the sisters also have similarities. For example, see lines 45-50, where Anna repeats Elsa's lines:

Elsa: But it's only for today

Anna: It's only for today

Elsa: It's agony to wait

Anna: It's agony to wait

Elsa: Tell the guards to open up the gates

Anna: The gates ('For the first time in forever', lines 45-50)

The target version, interestingly, maintains the distinction between the characters in its singability, and much of the repetition and unifying nature of the rhyme scheme in the rest of the song has been removed to accentuate that distinction. Lines $45-50$, for example, are translated as follows:

Elsa: Gelukkig duurt het maar een dag ('Fortunately, it only lasts a day')

Anna: Al duurt het maar een dag ('Even though it only lasts a day')

Elsa: Alleen omdat het hoort ('Only because it is supposed to be like this')

Anna: Dit is zoals het hoort ('This is how it's supposed to be')

Elsa: Goed dan, wachter, open nu de poort ('All right, guard, open up the gate')

Anna: De poort ('The gate') ('For the first time in forever', Dutch dub, lines 45-50) 
Instead of Anna repeating Elsa's lines here with merely a different intention, Anna actively restates and subverts Elsa's lines, widening the distance between them. In the target version, then, the distinction between love and fear is starker than in the source version, and Elsa, being less in tune with Anna (who is arguably the film's main protagonist), is rendered perhaps less relatable to Dutch audiences than to English-language audiences.

'For the first time in forever (reprise)' is a more immediate duet between Elsa and Anna: whereas in the first song they express their sentiments concerning the same event separately, in the reprise they address each other directly. Anna, again as a representation of love, attempts to convince Elsa to come back with her and unfreeze the city, while Elsa, as a representation of fear, attempts to explain why she is unable to do so: 'Just stay away and you'll be safe from me' (line 23). The target version of line 23 is 'Dus ga naar huis naar 't zomerjaargetij' ('So go home to summertide'), expressing perhaps more clearly than the source version that Elsa does not know she froze the city (although this is merely a compensation for line 17 , where the target version makes no mention of the sun while the source version does), but also weakening Elsa's motivation for her isolation and her role as a symbol of fear. However, that is no consistent trend in the song, and the target version embraces the theme of love versus fear, as well as the narrative symbolism of Anna versus Elsa and the visual symbolism of the storm versus sunlight, about as effectively as the source version. The target version makes mention of the storm as it is visually brewing in the third verse, just like the source version, and while the source version makes explicit mention of the sun to reinforce its role and a symbol of love in line 48 ('We'll make the sun bright'), there is no visual representation of sunlight at that moment, so the target version opts for a more direct expression of Anna's sentiment instead: 'Want ik zal naast je staan' ('Because I will stand next to you'). Although the distinction in singability between the characters is reduced in the target version, there are relatively few major synchronic differences; the most prominent instances of visual deixis have been retained; and in both versions the rhyme scheme provides a connection between the sisters. Overall, then, the target version, although different to some degree, is roughly as effective as the source version in its development of the theme of love versus fear. 
The dichotomy of love and fear can also be seen in a juxtaposition of the first song, 'Frozen heart', representing fear, and the last song, 'Fixer upper', representing love. In this sense, the narrative development moves from fear to love: fear is conquered and love is what we should strive for. In 'Frozen heart', the minor-key music, based around the tonic and dominant fifth chords, evokes a grounded sense of looming danger, and the dark colours and sudden, strong movements on the screen stress the great unknown beyond the ice miners' lanterns. Although the lyrics do mention the beauty of ice (e.g. line 3, 'This icy force both foul and fair', lines 7-8, 'Strike for love and / Strike for fear', and lines 9-10, 'See the beauty / Sharp and sheer'), these instances of beauty are always followed or preceded directly by warnings about the dangers of ice. The song explains that one can only appreciate ice if one is aware of the dangers and cautious enough to avoid them. While the target version's lines 9-10 maintain this opposition of beauty and danger, the opposition is less clear in line 3, 'Verbergt een kracht heel puur en rauw' ('Hides a power so pure and raw', 'pure' not including the connotations of pristine cleanness) and lines 7-8, 'Splijt het hart / Verkild en zwaar' ('Split the heart / Cold and heavy'). This reduced semantic and metaphoric weight of the theme is mirrored in the song's synchrony, which comprises great incongruence between characters' mouth movements and the syllables they sing, thus weakening their emotional impact and perceived authority; and its visual deixis, where most of the references have been removed, including those relating to Kristoff, the only main character in the song. The target version's rhyme, rhythm, and singability are quite similar to the source version, supporting the characters' authority and the severity of their warning. Despite that, however, the theme of love versus fear is significantly less central to the song in the target version than in the source version, and the target version instead focuses more on the explicit warning, or fear.

'Fixer upper' provides a contrast to the danger and darkness of 'Frozen heart'. Its music is major-key, optimistic, and fast-paced, and its chord progressions use primarily major chords (even if those chords do not fit the key, which stresses the importance of major chords and optimism in the song). Visually, the song takes place at night, like 'Frozen 
heart', but the movements are fast-paced and smooth (as opposed to the sharp movements of 'Frozen heart') and there are festive, colourful lights everywhere. The song's message of love trumping fear is expressed most explicitly in lines 53-58, culminating in 'True love brings out the best'. In the target version, this line is translated as 'Want liefde doet de rest' ('Because love does the rest', referring to fixing people by giving them love): this version, and with it the entire target version verse of lines 53-58, provides a level of clarity of the development of love versus fear quite similar to the source version. Concerning rhyme and rhythm, the target version is slightly less unified than the source version, but it is slightly more singable, which might compensate for the rhyme and rhythm. Visually, too - and despite some serious synchronic differences - the target version presents a quite coherent image of the theme. The style, which in other songs is somewhat old-fashioned and archaic in the target version, is about as colloquial in this song in both versions. As a result, the theme of love conquering fear is roughly as prominent in the target version as it is in the source version. One possible explanation for this might be the prominence of the theme in the source version: whereas most other songs incorporate multiple themes and instances of character development, the importance of love is without a doubt the main theme of 'Fixer upper', and its treatment in the Dutch dubbed version reflects that.

\section{CONCLUSION}

This study aimed to uncover how the theme of love versus fear was altered in the dubbing process of the Dutch dubbed songs of the 2013 Disney film Frozen. In most songs, the differences in the target version have dulled the development and prominence of the theme of love versus fear. While rhyme, rhythm, harmony, visual deixis, and imagery generally support the theme in the target version in a fashion similar to the source version, the role of singability is significantly less prominent, which distorts the careful balance (presented in the source version) between rhyme and rhythm on the one hand and singability on the other. The aspects of synchrony and style include many major differences in most songs, but other than weakening the perceived authority of the characters (such as in 'Frozen heart'), these differences seem to not have a significant effect on the theme of love versus 
fear. The aspect of sense, however, is quite essential in causing most large differences, especially in combination with singability (e.g. in 'Love is an open door'), visual deixis (e.g. in 'Frozen heart'), and mood (e.g. in 'Let it go'). In general, the theme of love versus fear has been simplified: songs including 'Love is an open door' and 'For the first time in forever' focus more strongly on love, rather than presenting love and fear as equally important and powerful, and 'Fixer upper', an ode to love, is the most explicit performance of the theme of love versus fear in the target version. Instead of introducing a compelling discussion on the topic of love versus fear, then, the target version focuses on the importance of love more extensively, and, by forgoing a thorough analysis of fear, expresses the message of love trumping fear in a less fully rounded manner, but also less ambiguously, than the source version.

The target version's development of the theme in a simplified and more straightforward form, then, implies that, while important, this theme may not have been considered an essential part of the film's purpose during the dubbing process. The separation of love and fear in the target version, and its focus on love over fear, suggest that love, at least, is a central theme in the target version - it is, after all, the driving force of the narrative, urging Anna, one of the main protagonists, to move the story forwards on several occasions - while the dichotomy between love and fear, which defines the relationship between Anna and Elsa as well as construes Elsa as a compelling character, is not as prominent. Anna, representing love, is defined more clearly as the film's main protagonist in the target version, whereas Elsa, representing fear, becomes more backgrounded and fulfils a slightly more traditional villainous role in the target version. The exception to this is the song 'For the first time in forever (reprise)', where Elsa is portrayed as an important and conflicted character rather than just a villain; however, this is only one song. As a result, the target version seems to concentrate more on the explicit narrative of the film (i.e. Anna's quest to save Arendelle) in favour of character development and, indeed, the thematic integration of Elsa's character in the film's narrative.

Another aim of this study was to test the usefulness of the triangle of aspects for the 
purpose of a thematic analysis. While an analysis of the themes of a text is perhaps inherently qualitative and subjective to a certain degree, this study has attempted to substantiate its findings through the use of quantitative tools. By describing ten aspects of animated musical films, the triangle of aspects offers researchers a guideline to assume a broader and more structured scope when analysing dubbed versions of animated musical films. This model may provide relevant concepts to research fields including audiovisual translation, song and film translation, the history of dubbing, the international export of Disney films, and musical translation. The data collected according to the triangle of aspects provides a clear structure and solid foundations to any analysis, but however useful this model may be, it should be noted that the analysis in this study and the interpretation of the results are still qualitative in nature, so not necessarily representative of the film or genre as a whole. Although the triangle of aspects as applied in this study offers insight into one of the most prominent themes of Frozen (Beaudry 2015), more research is needed to fully appreciate the model's capabilities and to further develop its usefulness. Further research may also concentrate on the themes and characters in other dubbed versions of Frozen, other Disney films, or films by other animation studios or of other animation styles, such as those by the prominent Japanese animation producer Studio Ghibli, to uncover what elements are prioritised in the dubbing process, what effects those priorities have, and how those priorities and effects change over time or vary between cultures. The multimodal field of animated musical film dubbing is fledgling in academia, and considering the genre's prominent role in many societies, there is much to learn.

\section{PRIMARY SOURCES}

Del Vecho, P. (producer), \& Buck, C., \& Lee, J. (directors). 2013. Frozen [Motion picture]. United States: Disney.

Kielipankki. 2019. Triangle of Aspects Analysis of Frozen [Data set]. Retrieved from http://urn.fi/urn:nbn:fi:lb-2019022701 


\section{REFERENCES}

Arnheim, R. 1974. Art and Visual Perception: A Psychology of the Creative Eye. Berkeley, Los Angeles, London: University of California.

Bauer, J., \& Steiner, B. 2015. Hidden Meaning in Disney’s Frozen — Earthling Cinema [Video file]. Wisecrack, Inc. Retrieved from https://www.youtube.com/watch?v=WpmKW10d_TU. (12 September, 2016)

Beaudry, K. 2015. Disney Melodies: The Magic of Disney Music. New York: Theme Park Press.

Chaume, F. 1997. Translating Non-Verbal Information in Dubbing. In Poyatos, F. (ed.), Nonverbal Communication and Translation. Amsterdam and Philadelphia: John Benjamins. 315-326.

Chaume, F. 2012. Audiovisual Translation: Dubbing. Manchester: St Jerome Publishing.

Clendinning, J. P., \& Marvin, E. W. 2010. The Musician's Guide to Theory and Analysis (2nd ed). New York: W. W. Norton \& Company.

Di Giovanni, E. 2008. The American Film Musical in Italy: Translation and NonTranslation. Translation and Music Vol. 14. No. 2. 295-318.

Franzon, J. 2008. Choices in Song Translation: Singability in Print, Subtitles and Sung Performance. Translation and Music Vol. 14. No. 2. 373-400.

Giese, F. 2017. Frozen Dub Collection. Retrieved from http://frozendubcollection.weebly.com/list-of-existing-dubs.html. (1 May, 2018)

Kaindl, K. 2005. The Plurisemiotics of Pop Song Translation: Words, Music, Voice and Image. In: Gorlée, D. L. (ed.) Songs and Significance: Virtues and Vices of Vocal Translation. Amsterdam and New York: Rodopy. 235-262.

Konnikova, M. 2014. How 'Frozen’ Took over the World. The New Yorker. Retrieved from https://www.newyorker.com/science/maria-konnikova/how-frozen-took-over-theworld. (25 May, 2018)

Labov, William and Joshua Waletzky. 1967. Narrative analysis. In: Helm, J. (ed.), Essays on the Verbal and Visual Arts. Seattle: University of Washington Press. 12-44.

Leech, G., \& Short, M. 2007. Style in Fiction: A Linguistic Introduction to English 
Fictional Prose. (2nd ed.) Harlow: Pearson Education.

Levinson, S. C. 2004. Deixis. In Horn, L. \& Ward, G. (eds.), The Handbook of Pragmatics. Oxford: Blackwell Publishing. 97-121.

Low, P. 2005. The Pentathlon Approach to Translating Songs. In: Gorlée, D. L. (ed.) Songs and Significance: Virtues and Vices of Vocal Translation. Amsterdam and New York: Rodopy. 185-212.

Low, P. 2017. Translating Songs: Lyrics and Texts. Abingdon and New York: Routledge.

Malach, M. 2014. Disney Renaissance: Why 'Frozen’ Is Reviving the Company’s Golden Era of Animated Films. Retrieved from http://popcrush.com/disney-renaissancefrozen-animated-films/. (11 October, 2016)

Martín-Castaño, M. 2017. Translating Disney Songs from The Little Mermaid (1989) to Tarzan (1999): An Analysis of Translation Strategies Used to Dub and Subtitle Songs into Spanish. Warwick: University of Warwick.

Pérez-González, Luis. 2014. Audiovisual Translation: Theories, Methods and Issues. London and New York: Routledge.

Reus, T. 2017. The Many Voices of Elsa and Anna: Introducing the Triangle of Aspects for Animated Musical Film Dubbing. VAKKI Publications Vol. 8. No. 1. 181-192.

Reus, T. 2018. Exploring Skopos in the Dutch Target versions of the Songs of Disney's Frozen. New Voices in Translation Studies Vol. 19. No. 1. 1-24.

Stopar, A. 2016. Mamma Mia, a Singable Translation! Translation Studies Vol. 13. No. 1. $141-159$.

Tråvén, M. 2005. Musical Rhetoric - The Translator's Dilemma: A Case for Don Giovanni. In: Gorlée, D. L. (ed.) Songs and Significance: Virtues and Vices of Vocal Translation. Amsterdam and New York: Rodopy. 103-120.

Wensink, H. 2014. Frozen: De Commerciële (Kunstzinnige) Truc van het Jaar. NRC Q. Retrieved from http://www.nrcq.nl/2014/12/31/frozen-de-commerciele-kunstzinnigetruc-van-het-jaar. (11 November, 2016)

Yee, K. 2014. Let it Go: A Quick Academic Analysis of Disney's Frozen. Central Florida: Ultimate Orlando Press. 